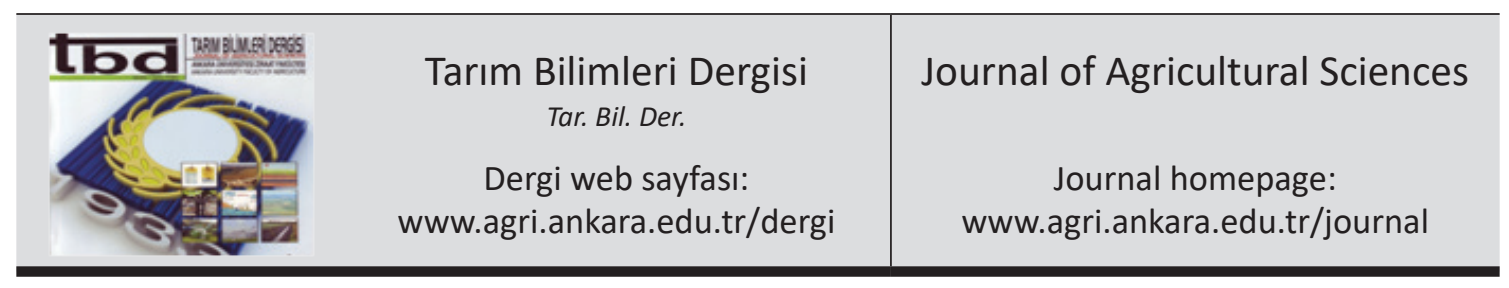

\title{
Influence of Pollination on Smut Disease and Yield in Maize
}

\author{
Mehmet AYDOĞDU ${ }^{\mathrm{a}}$, Nuh BOYRAZ \\ ${ }^{a}$ Batı Akdeniz Agricultural Research Institute, Department of Plant Health, Antalya, TURKEY \\ ${ }^{b}$ Selçuk University, Faculty of Agriculture, Department of Plant Protection, Konya, TURKEY
}

\section{ARTICLE INFO}

Research Article DOI: 10.15832/ankutbd.490958

Corresponding Author: Mehmet AYDOĞDU, E-mail: mehmet9498@yahoo.com, Tel: +90 (533) 7268985

Received: 09 March 2017, Received in Revised Form: 05 September 2017, Accepted: 01 November 2017

\begin{abstract}
Ustilago maydis, causal agent of smut disease in maize, induces significant yield losses by forming colossal galls (tumours) on cobs. Since infection process of $U$. maydis is parallel with natural pollination of maize, an interaction between maize pollination and the smut fungus is probable. To reveal this interaction perceptibly, a 2-year field study was carried out in Antalya province of Turkey. As host plants, 8-maize-cultivars belonging to different maize variety groups [dent (Ada-523, Pioneer-3394 and Side), flint (Karaçay and Karadeniz Y1ldızı), sweet (Merit and Vega) and popcorn (Antcin-98)] were used in the experiment. Inoculations were performed by injecting inoculum into cob silks in pre- and post-pollination periods in plots. In addition, control plots were set up for each treatment. In conclusion, average disease severity, incidence and yield losses of all the maize cultivars in pre-pollination inoculations (PrePI) were 3.8, 20.7 and 45.5\%, whereas in post-pollination (PostPI) inoculations, they were $0.9,15.7$ and 35.9\%, respectively. It was found that in both years, disease values of the PrePI were higher than those of the PostPI. This study suggested that pollination period of maize is an important factor affecting $U$. maydis infection in cobs and accordingly yield losses.

Keywords: Maize pollination; Ustilago maydis; Yield loss
\end{abstract}

(C) Ankara Üniversitesi Ziraat Fakültesi

\section{Introduction}

Maize is a staple crop for human and animal nutrition as well as fodder industry (Kirtok 1998). In 2013, total maize production in the world exceeded one billion tons (FAO 2015). However, Ustilago maydis (DC) Corda, called also as corn smut, is one of the primary constraint to maize yield. The disease occurs wherever maize is grown. Unlike other cereal smuts, U. maydis gives rise to local infections and severe damages to cobs through formation of huge galls on them (Tunçdemir \& Iren 1980). In addition, it particularly causes great economic damage to sweet corn (du Toit \& Pataky 1999).
When maize seedlings are infected by the fungus, small galls appear on the leaves and stems, and the seedling may remain stunted or may be killed. On older plants, infections occur on the young, actively growing tissues of axillary buds, individual flowers of the cob and tassel, leaves and stalks. Infected areas are permeated by the fungus mycelium, which stimulates the host cells to divide and enlarge, thus forming galls. Galls are first covered with a greenish white membrane. Later, as the galls mature, their interior darkens and turns into a mass of powdery, dark olive-brown spores (Agrios 2005). U. maydis infects stigmas in maize cobs via silks at the tip 
of the cob. Sporidia of the fungus accumulate on silks (Shurtleff 1980). Infection process of stigma by the fungus is as follows: when fungus sporidia contact with stigma, sporidia mate in pairs and each pair forms a dikaryotic infection hypha and then enter the stigma. Similarly, fertilization of stigma by pollens occurs as follows: pollens moving from tassels pass through the silk channel and reach to stigma and fertilize ovaries. Following pollination, an abscission zone consisting of layer of dead cells in pollinated silks occurs. U. maydis is not able to grow across this abscission zone (Snetselaar \& Mims 1993; Snetselaar et al 2001). This phenomenon suggests that when the pollens reach to the ovary earlier than the infective hypha of the fungus, $U$. maydis infection in the cobs become formidable. Correspondingly, plant may escape from the infection.

The main objectives of the study were to perceptibly examine this phenomenon by injecting inoculum into cob silks of different maize varieties in pre and post pollination periods and determine yield losses arising from the fungus infection during pollination period.

\section{Material and Methods}

Galls on cobs were obtained from naturally infected plants in maize-producing areas of Batı Akdeniz Agricultural Research Institute in 2010. Flint corn varieties [Karaçay (Batı Akdeniz Agricultural Research Institute) (BAARI) and Karadeniz Yıldizı (Black Sea Agricultural Research Institute)], dent corn cultivars [Ada-523 (Maize Research Institute), Pioneer-3394 (Pioneer Firm) and Side (BAARI)], sweet corn cultivars [Merit (May Firm) and Vega (May Firm)], and popcorn variety [Antcin-98 (BAARI)] were used as host plants.

\subsection{Isolation}

Teliospores of $U$. maydis, also named as chlamydospores, were obtained by crumbling and filtering out the galls. Teliospores were exposed to $1 \%$ copper sulfate solution for 20 to $60 \mathrm{~h}$. Afterwards, they were dried up using blotting paper, and transmitted on PDA medium and incubated at $25{ }^{\circ} \mathrm{C}$. Within a week, basidiospores (sporidia) of the fungus appeared. Later, they were transmitted to a $20 \%$ carrot solution in $500 \mathrm{~mL}$ flasks and incubated at $25{ }^{\circ} \mathrm{C}$ for one week. In this way, necessary inoculum was obtained.

\subsection{Inoculum}

With gently shaking the flasks, sporidia were moved to ensure homogeneity of the spore solution. By means of a hemocytometer, sporidia and teliospore suspensions were arranged to $3 \times 10^{6}$ basidiospores $\mathrm{mL}^{-1}$ and $1 \times 10^{6}$ teliospores $\mathrm{mL}^{-1}$, respectively. In this manner, inoculum was arranged according to Tunçdemir (1985).

\subsection{Experiments}

Experiments were conducted in completely randomized block factorial design with three replicates. Plots, $5 \mathrm{~m}$ long, were set up as four rows including controls. Seeds of the each cultivar were sown on 7 June in 2010 and on 3 June in 2011. Mean number of the plants in every plot were one hundred. Furrow irrigation was used and irrigation, a total of 9 times, was done at 15 to 18 days intervals depending on the moisture in the soil. To manage with weeds, the herbicide, foramsulfuron $22.5 \mathrm{~g} \mathrm{~L}^{-1}$ (active substance), was used at 2 to 6 leaf stage of maize. However, deltamethrin $25 \mathrm{~g} \mathrm{~L}^{-1}$ (active substance), was applied at silking stage against earworms. Picking ears by hand from the each plot, harvest was done. Harvest times were on 26 to 29 October in 2010, while they were on 10 to 12 October in 2011.

\subsection{Ecological properties of the research area}

General soil texture of the research area was clay loam. In sowing-time, the area was fertilized with compound fertiliser (NPK 18:8:8) at the rates of 180 nitrogen, 80 phosphorus and 80 potassium $\mathrm{kg}$ $\mathrm{ha}^{-1}$, respectively. Field studies were established in Aksu location of Antalya. The total monthly rainfall when the inoculations of the maize ears were performed in August of 2010 was $4.2 \mathrm{~mm}$, whereas no measurable rainfall was recorded in the same 
period in 2011. However, the average temperature and relative humidity in August 2010 and 2011 were $30.5{ }^{\circ} \mathrm{C}, 59.1 \%$ and $29.6{ }^{\circ} \mathrm{C}$ and $50.0 \%$, respectively (Anonymous 2013).

\subsection{Inoculation}

The cob inoculation method of Pataky et al (1995) was modified as follows: In total, $3 \mathrm{~mL}$ mixed inoculum, consisted of $3 \times 10^{6}$ basidiospores $\mathrm{mL}^{-1}$ and $1 \times 10^{6}$ teliospores $\mathrm{mL}^{-1}$, was syringed in primary cob in pre-pollination period ( 3 days before natural pollination of maize) and in the post-pollination period (3 days after silk browning) per plant. In 2010, inoculations of PrePI and PostPI were performed on August $10^{\text {th }}$ and $20^{\text {th }}$, while in 2011, those inoculations were applied on August $15^{\text {th }}$ and $25^{\text {th }}$, respectively. In the control plots, cobs were injected with sterile water.

\subsection{Disease assessments}

Using 0 to 5 scale of Johnson \& Christensen (1935), severity of the disease was determined. Rating of the scale was as follows: $5=$ big galls $(>10 \mathrm{~cm}$ diam); $2.5=$ medium galls $(5$ to $10 \mathrm{~cm}$ diam $) ; 1=$ small galls $(2.5$ to $5 \mathrm{~cm}$ diam); and $0=$ very small galls $(<2.5 \mathrm{~cm}$ diam). Comparing the number of infected and non-infected cobs, incidence of the disease was detected. Twenty cobs were assessed in each plot for each treatment. In 2010, disease incidence and severity ratings of PrePI and PostPI were done on September $2^{\text {nd }}$ and $10^{\text {th }}$, whereas in 2011 , those ratings were assessed on September $6^{\text {th }}$ and $14^{\text {th }}$, respectively. To determine yield losses of the hosts, cobs collected from the plots were peeled from the cob leaves and dried. Leaving kernels at $72{ }^{\circ} \mathrm{C}$ for $72 \mathrm{~h}$, moisture contents were found. Adjustment of yield was done in compliance with $15 \%$ moisture ratio and using Equation (1) of Poehlman (1987) below.

Adjusted weight $=$ Plot weight $\times(100-$ moisture $\%) /$ $85 \times(\mathrm{kernel} / \mathrm{cob}) / 100$

Ratio of kernel/cob and plot yield were detected using Equation (2) of Yanıkoğlu et al (1999).
Plot yield $\left(\mathrm{kg} \mathrm{ha}^{-1}\right)=$ Adjusted weight $\times 10000 /$ Plot area $\left(\mathrm{m}^{2}\right)$

In conclusion, yield losses were designated by comparing yields of inoculated plots with noninoculated plots.

\subsection{Statistical analysis}

Analysis of variance was done using JMP program (SAS Institute Inc., Cary, North Carolina, USA) and average values established as different were categorized considering $\operatorname{LSD}_{0.01}$.

\section{Results and Discussion}

Average disease incidence (DI) of all the cultivars (hosts) in PrePI was 20.7\%, whereas in PostPI, that was $15.7 \%$. However, the highest DI in the PrePI and PostPI were found in cv. Karadeniz Yildizi and cv. Side, whereas the lowest DI was in cv. Antcin-98 (Table 1). Likewise, average disease severity (DS) of all the hosts in the PrePI was found at the rate of 3.8, while in the PostPI, it was 0.9 (Table 2). In both years, average DS and DI of the hosts in the PrePI were higher than that of the PostPI. In 2010, average yields of the cultivars in the control, PrePI and PostPI plots were 8180, 5240 and $5950 \mathrm{~kg} \mathrm{ha}^{-1}$, respectively. However, in 2011, they were 7510 , 3060 and $3730 \mathrm{~kg} \mathrm{ha}^{-1}$, respectively. In addition, as an average of both years, mean yields of the hosts in the control, PrePI and PostPI were 7850, 4150 and $4850 \mathrm{~kg} \mathrm{ha}^{-1}$, respectively. Interactions of the year, cultivar, and year $\times$ cultivar $\times$ disease in the PrePI and PostPI were significant $(\mathrm{P}<0.01)$ in both years (Table 3).

In 2010, average yield losses of the hosts in the PrePI and PostPI were $36.5 \%$ and $28.0 \%$, while in 2011, they were $55.5 \%$ and $44.7 \%$, respectively. Mean yield loss of the hosts over the two years in the PrePI was determined at the rate of $45.5 \%$, whereas in the PostPI, it was $35.9 \%$. Compared all the hosts, the highest yield losses in the PrePI (52.4\%) and PostPI (43.8\%) were established from Ada-523 (dent corn variety). However, the lowest yield losses in the PrePI (38.4\%) and in the PostPI (26.2\%) were found in the popcorn variety, Antcin-98 (Table 4). 
Table 1- Disease incidence of the cultivars in pre and post pollination inoculations (\%)

\begin{tabular}{lcccccc}
\hline \multirow{2}{*}{ Cultivar (host) } & \multicolumn{4}{c}{ Disease incidence in PrePI } & \multicolumn{3}{c}{ Disease incidence in PostPI ${ }^{2}$} \\
\cline { 2 - 6 } & 2010 & 2011 & Mean & 2010 & 2011 & Mean \\
\hline Ada-523 & $13.3^{*}$ & 26.6 & 19.9 & 8.3 & 16.6 & 12.4 \\
Pioneer-3394 & 15.0 & 36.6 & 25.8 & 10.0 & 30.0 & 20.0 \\
Side & 13.3 & 50.0 & 31.6 & 8.3 & 36.6 & 22.4 \\
Karaçay & 3.3 & 33.3 & 18.3 & 3.3 & 28.3 & 15.8 \\
Karadeniz Y1ld1z1 & 20.0 & 38.3 & 29.1 & 18.3 & 31.6 & 24.9 \\
Merit & 16.6 & 20.0 & 18.3 & 10.0 & 15.0 & 12.5 \\
Vega & 13.3 & 15.0 & 14.1 & 10.0 & 15.0 & 12.5 \\
Antcin-98 & 6.6 & 11.6 & 9.1 & 3.3 & 8.3 & 5.8 \\
Mean & 12.6 & 28.9 & 20.7 & 8.9 & 22.6 & 15.7 \\
\hline \multicolumn{4}{c}{ Year LSD $(0.01)=2.5$} & \multicolumn{3}{c}{ Year LSD $(0.01)=1.9$} \\
& Cultivar LSD $(0.01)=5.1$ & Cultivar LSD $(0.01)=3.8$ \\
& Year x cultivar LSD $(0.01)=7.3$ & Year x cultivar LSD $(0.01)=5.4$ \\
\hline
\end{tabular}

*, data are means of three replications; $\mathrm{PrePI}^{1}$, pre-pollination inoculations; $\mathrm{PostPI}^{2}$, post-pollination inoculations

Table 2- Disease severity of the cultivars in pre and post pollination inoculations

\begin{tabular}{lcccccc}
\hline \multirow{2}{*}{ Cultivar (host) } & \multicolumn{3}{c}{ Disease severity in PrePI** } & \multicolumn{3}{c}{ Disease severity in PostPI** } \\
\cline { 2 - 7 } & 2010 & 2011 & Mean & 2010 & 2011 & Mean \\
\hline Ada-523 & $1.5^{*}$ & 6.8 & 4.1 & 0.5 & 2.0 & 1.2 \\
Pioneer-3394 & 1.7 & 4.2 & 2.9 & 0.3 & 0.8 & 0.5 \\
Side & 2.9 & 10.5 & 6.7 & 0.6 & 2.6 & 1.6 \\
Karaçay & 0.8 & 7.4 & 4.1 & 0.3 & 2.2 & 1.2 \\
Karadeniz Y1ldız1 & 3.2 & 11.4 & 7.3 & 0.8 & 3.7 & 2.2 \\
Merit & 2.4 & 2.3 & 2.3 & 0.6 & 0.5 & 0.5 \\
Vega & 2.5 & 1.7 & 2.1 & 0.3 & 0.6 & 0.4 \\
Antcin-98 & 0.5 & 1.4 & 0.9 & 0.1 & 0.3 & 0.2 \\
Mean & 1.9 & 5.7 & 3.8 & 0.4 & 1.5 & 0.9 \\
\hline \multicolumn{4}{c}{ Year LSD $(0.01)=0.2$} & \multicolumn{3}{c}{ Year LSD $(0.01)=0.1$} \\
& \multicolumn{4}{c}{ Cultivar LSD $(0.01)=0.4$} & Cultivar LSD $(0.01)=0.2$ \\
& Year x cultivar LSD $(0.01)=0.6$ & Year x cultivar LSD $(0.01)=0.3$ \\
\hline
\end{tabular}

**, the highest disease severity value was accepted as $10.0 ; *$, data are means of three replications

In both years, average DS, DI and yield losses of all the maize cultivars in the PrePI were higher than those in the PostPI (Table 1 and 2). In the study, inoculations performed in the pre-pollination period induced a higher DS, DI and yield losses on the cultivars than those in the PostPI treatments. These findings revealed that irrespective of the host, injection of $U$. maydis during pre-pollination of maize caused more severe smut infection in cobs than those in the post-pollination period. The results of the present study corroborated the earlier findings of Snetselaar et al (2001). These authors reported that an abscission layer appeared at the bottom of pollinated cob silks, which may preclude ovaries from infection of $U$. maydis in maize cobs. Similarly, du Toit \& Pataky (1999) underscored that 


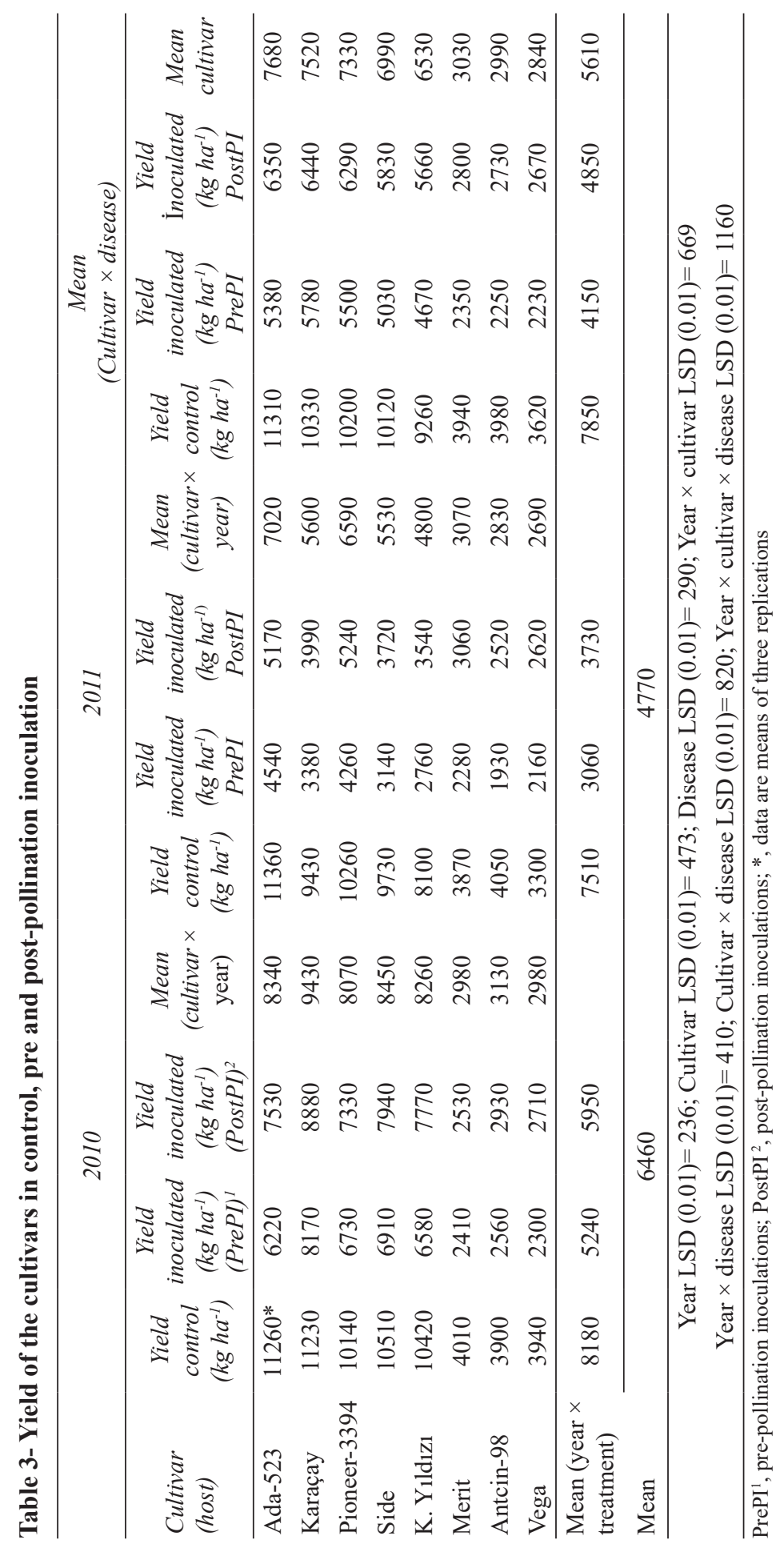

Tarım Bilimleri Dergisi - Journal of Agricultural Sciences $\quad \mathbf{2 4}(2018)$ 463-470 
Table 4- Mean yield losses of the cultivars tested

\begin{tabular}{lcccccc}
\hline & \multicolumn{2}{c}{2010} & \multicolumn{2}{c}{2011} & \multicolumn{2}{c}{ Mean } \\
\cline { 2 - 6 } Cultivar (host) & $\begin{array}{c}\text { Yield loss } \\
\text { (\%) }\end{array}$ & $\begin{array}{c}\text { Yield loss } \\
(\%)\end{array}$ & $\begin{array}{c}\text { Yield loss } \\
(\%)\end{array}$ & $\begin{array}{c}\text { Yield loss } \\
(\%)\end{array}$ & $\begin{array}{c}\text { Yield loss } \\
(\%)\end{array}$ & $\begin{array}{c}\text { Yield loss } \\
(\%)\end{array}$ \\
& PrePI $^{1}$ & PostPI $^{2}$ & PrePI & PostPI & PrePI & PostPI \\
\hline Ada-523 & 44.7 & 33.1 & 60.0 & 54.4 & 52.4 & 43.8 \\
Pioneer-3394 & 33.6 & 27.7 & 58.4 & 48.9 & 50.2 & 42.3 \\
Side & 34.2 & 24.4 & 67.7 & 61.7 & 44.0 & 37.6 \\
Karaçay & 27.2 & 20.9 & 64.1 & 57.6 & 46.0 & 38.3 \\
Karadeniz Y1ldiz1 & 36.8 & 25.4 & 65.9 & 56.2 & 49.5 & 38.8 \\
Merit & 39.9 & 36.9 & 41.1 & 20.9 & 40.3 & 28.9 \\
Vega & 41.6 & 31.2 & 34.5 & 20.6 & 43.4 & 31.4 \\
Antcin-98 & 34.3 & 24.8 & 52.3 & 37.8 & 38.4 & 26.2 \\
Mean & 36.5 & 28.0 & 55.5 & 44.7 & 45.5 & 35.9 \\
& & & 50.1 & & 40.7 \\
\hline
\end{tabular}

PrePI $^{1}$, pre-pollination inoculations; PostPI $^{2}$, post-pollination inoculations

maize cobs were susceptible to the smut fungus from the beginning of silk arising until the two week after silking period of maize. In the course of this vulnerability period, amount of infected cobs reduced with silk aging. In addition, Snetselaar \& Mims (1993) postulated that unpollinated cobs were more vulnerable to $U$. maydis infection than pollinated ones.

Vulnerability of maize to fungi colonizing cobs via silks alternates depending on silk maturity e.g., Fusarium graminearum, causes ear rot in maize, was highest if silks were inoculated soon after beginning of silk arising and diminished drastically with silk maturity (Enerson \& Hunter 1980; Reid et al 1992; du Toit \& Pataky 1999). Furthermore, several researchers (Marsh \& Payne 1984; Headrick et al 1990) revealed similar results regarding Fusarium moniliforme and Aspergillus flavus, another cob infecting fungi. Considering all of these, the findings of the present study and aforementioned authors have been suggested that occurrence of maize pollination prior to U. maydis infection in cobs renders ovaries more resistant to the fungus.

Of all maize varieties, the highest DS in the PrePI and PostPI was found in Karadeniz Yıldizı (flint corn variety), whereas the lowest DS was in Antcin-98 (popcorn variety) (Table 2). As it had more severe smut gall on its cobs, Karadeniz Yildızı was more vulnerable to infection of $U$. maydis than the other varieties. However, the cobs of Antcin-98 were less affected by the fungus than the others. In the present study, among the varieties, the DS values were ranked according to host's gall size (from largest to smallest) as follows: Flint, dent, sweet, and popcorn, respectively. It can be concluded that the bigger the cobs, the higher the development of large smut galls on them; flint and dent corn varieties showed higher DS values than the others. In addition, DI values in the study were similar to DS values. These results supported the earlier findings of Pataky \& Snetselaar (2006). These authors reported that incidence of smut infection was greater than $50 \%$ in 1976 in several areas of Germany where hybrids derived from European flint corn were prevalent. Similarly, in a study conducted by Bojanowski (1969) in Poland, U12 (a flint corn inbred) was identified as susceptible to corn smut. Pataky (1991) stated that extremely susceptible genotypes may exist among dent, flint, floury and other types of corn. In addition, Aydoğdu (2015) was reported that flint and dent corn cultivars were susceptible to $U$. maydis infection.

The average DS, DI and yield losses of all the hosts in 2011 were higher than those in 2010 (Tables $1,2,3$ and 4). Year-to-year variation found in the present study could be explained as follows: it is 
known that environmental conditions can influence the development of diseases, in particular during penetration and infection of the host. Tunçdemir \& Iren (1980) reported that the most favorable temperature for development of maize smut ranges between 18 ${ }^{\circ} \mathrm{C}$ and $21{ }^{\circ} \mathrm{C}$. In this regard, in 2010 , the average daily temperature on the inoculation day of PrePI and PostPI were $30.2{ }^{\circ} \mathrm{C}$ and $31.6^{\circ} \mathrm{C}$, whereas in 2011 , they were $27.2^{\circ} \mathrm{C}$ and $27.3{ }^{\circ} \mathrm{C}$, respectively (Table 5). Therefore, those temperatures may have adversely affected germination and penetration of the fungus in 2010. However, mean relative humidity $(\mathrm{RH})$ of the August in 2010 was $59.1 \%$, while it was $50.0 \%$ in 2011. In addition, the environmental conditions in 2010 may have been favorable for the host. Because, in 2010, average yield of all the hosts in the control plots was $8180 \mathrm{~kg} \mathrm{ha}^{-1}$, while in 2011, it was 7510 $\mathrm{kg} \mathrm{ha}^{-1}$ (Table 3). Depending on these factors, in 2010, average yield loss of all the maize varieties was $32.2 \%$, but in 2011, it was $50.1 \%$ (Table 4). Kyle
(1929) emphasized that when environmental factors are in favor of the host during the maize growing season, smut infection levels are reduced. In a twoyear study conducted in Germany, Görtz et al (2008) stated that in 2006, the frequency of kernel infected by Fusarium spp. ranged from $0.7 \%$ to $99.7 \%$, while in 2007, the highest incidence of Fusarium ear rot was $64 \%$. The authors expressed that the year-toyear variability in the overall infection rate may be explained by significant differences in temperature and precipitation during the growth periods.

Apart from these factors, plant nutrition can affect smut infection. Aydoğdu \& Boyraz (2011) reported that nitrogenous and organic fertilization may affect the severity of the disease. Additionally, physiology and morphological structure of the host have an impact on colonization of $U$. maydis. Since maize cultivars tested have specific physiology and morphological features, different disease values

Table 5- Daily mean temperature of the research area during inoculations

\begin{tabular}{|c|c|c|c|c|c|}
\hline Inoculation & $\begin{array}{c}\text { Inoculation } \\
\text { date } \\
2010\end{array}$ & $\begin{array}{c}\text { Daily average } \\
\text { temperature } \\
\left({ }^{\circ} \mathrm{C}\right)\end{array}$ & Inoculation & $\begin{array}{c}\text { Inoculation } \\
\text { date } \\
2011\end{array}$ & $\begin{array}{c}\text { Daily average } \\
\text { temperature } \\
\left({ }^{\circ} \mathrm{C}\right)\end{array}$ \\
\hline PrePI & 10 August & 30.2 & PrePI & 15 August & 27.2 \\
\hline PostPI & 20 August & 31.6 & PostPI & 25 August & 27.3 \\
\hline
\end{tabular}

Source: Regional Meteorology Station, Antalya

were determined in the present study. Pataky \& Richter (2007) emphasized that leaves surrounding cobs may influence silks and accordingly infection of U. maydis. Pataky \& Chandler (2003) also emphasized that gall size induced by $U$. maydis varies depending on maize genotypes, virulency of the pathogen, and climatic conditions. A cultivartrial in the Columbia Basin in the U.S showed marked differences in susceptibility to corn smut between field corn hybrids (Mohan et al 2013).

\section{Conclusions}

Corn smut is a devastating disease of maize when environmental conditions are favourable for the fungus. In our study, for the first time, yield losses on the cobs, stemming from $U$. maydis infection, were revealed perceptibly based on interactions between maize pollination and $U$. maydis. The present study also suggested that pollination has an influence on $U$. maydis infection in cobs and correspondingly yield losses. Considering maize phenology and this host-pathogen interaction in cobs during maize pollination, new control methods can be developed. Taking into account all, further studies are needed to establish management strategies against the fungus.

\section{Acknowledgements}

This study was conducted within the scope of a $\mathrm{PhD}$ thesis (12201067), funded by Selçuk University, Konya, Turkey. 


\section{References}

Agrios G N (2005). Plant Pathology, Fifth Edition. Elsevier Academic Press, USA

Anonymous (2013). http://www.antalya.mgm.gov.tr/ sondurum/turkiye.aspx (Access date: 04.08.2013)

Aydoğdu M (2015). Huitlacoche yield in some maize varieties in the Mediterranean region of Turkey. Food Science and Technology (Campinas) 35(2): 386-390

Aydoğdu M \& Boyraz N (2011). Effects of nitrogen and organic fertilization on corn smut (Ustilago maydis (DC) Corda.). African Journal of Agricultural Research 6(19): 4539-4543

Bojanowski J (1969). Studies of inheritance of reaction to common smut in corn. Theoretical and Applied Genetics 39(1): 32-42

du Toit L J \& Pataky J K (1999). Effects of silk maturity and pollination on infection of maize ears by Ustilago maydis. Plant Disease 83: 621-626

Enerson P M \& Hunter R B (1980). A technique for screening maize (Zea mays L.) for resistance to ear mold incited by Gibberella zeae (Schw.) Petch. Canadian Journal of Plant Science 60: 1123-1128

FAO (2015). http://faostat3.fao.org/browse/Q/QC/E (Access date: 05.05.2015)

Görtz A, Oerke E C, Steiner U, Waalwijk C, Vries I D \& Dehne H W (2008). Biodiversity of Fusarium species causing ear rot of maize in Germany. In: $3^{\text {rd }}$ FHB Symposium, 1-5 September, Szeged, Hungary, pp. 617

Headrick J M, Pataky J K \& Juvik J A (1990). Relationships among carbohydrate content of kernels, condition of silks after pollination and the response of sweet corn inbred lines to infection of kernels by Fusarium moniliforme. Phytopathology 80: 487-494

Johnson I J \& Christensen J J (1935). Relation between number, size and location of smut infections to reduction in yield of corn. Phytopathology 25: 223-233

Kirtok Y (1998). Misır Üretimi ve Kullanımı. Kocaoluk Basım ve Yayınevi, İstanbul

Kyle C H (1929). Relation of husk covering to smut of corn ears. U.S. Department of Agriculture Technical Bulletin: 120, pp. 1-7

Marsh S F \& Payne G A (1984). Preharvest infection of corn silks and kernels by Aspergillus flavus. Phytopathology 74: 1284-1289

Mohan S K, Hamm P B, Clough G H \& du Toit L J (2013). Corn Smuts. A Pacific Northwest Extension
Publication. Oregon State University-University of Idaho-Washington State University, PNW 647

Pataky J K (1991). Production of cuitlacoche [Ustilago maydis (DS) Corda] on sweet corn. Hortscience 26(11): 1374-1377

Pataky J K \& Chandler M A (2003). Production of huitlacoche, Ustilago maydis: Timing inoculation and controlling pollination. Mycologia 95(6): 1261-1270

Pataky J K \& Snetselaar K M (2006). Common smut of corn. The plant health instructor. http:/www.apsnet. org/edcenter/intropp/lessons/fungi/Basidiomycetes/ Pages/CornSmut.aspx (Access date: 04.04.2015)

Pataky J K \& Richter P M (2007). Silk abscission in two sweet corn (Zea mays L.) hybrids that differ in susceptibility to common smut infection of ears. HortScience 42(6): 1409-1412

Pataky J K, Nankam C \& Kerns M R (1995). Evaluation of a silk-inoculation technique to differentiate reactions of sweet corn hybrids to common smut. Phytopathology 85: 1323-1328

Poehlman J M (1987). Breeding field crops. Avi Publishing Company, INC, Wesport, Connecticut, USA

Reid L M, Bolton A T, Hamilton R I, Woldemariam T \& Mather D E (1992). Effect of silk age on resistance of maize to Fusarium graminearum. Canadian Journal of Plant Science 14: 293-298

Shurtleff M C (1980). Compendium of corn diseases. $2^{\text {nd }}$ edition American Phytopathology Soc. St. Paul, MN, USA

Snetselaar K M \& Mims C W (1993). Infection of maize stigmas by Ustilago maydis, light and electron microscopy. Phytopathology 83: 843-850

Snetselaar K M, Carfioli M A \& Cordisco K M (2001). Pollination can protect maize ovaries from infection by Ustilago maydis, the corn smut fungus. Canadian Journal of Botany 79(12): 1390-1399

Tunçdemir M (1985). Buğday ve mısır hastalıkları semineri. Orta Anadolu Bölge Zirai Araştırma Enstitüsü, 25-29 Mart, Ankara

Tunçdemir M \& Iren S (1980). Samsun ve çevresinde mısır rastığı (Ustilago maydis (DC) Corda.) 'nin biyoekolojisi üzerinde araştırmalar. Ankara Üniversitesi Ziraat Fakültesi Diploma Sonras1 Yüksekokulu İhtisas Tez Özetleri, Ankara Basımevi

Yanıkoğlu S, Küçük İ, Sezer M C \& Meriç H (1999). Mısır Gözlem Klavuzu. Tarım ve Köyişleri Bakanlığı, Tagem, Sakarya Tarımsal Araştırma Enstitüsü Müdürlüğü, Yayın No: 12 